\title{
Regulation of mRNA export in response to stress in Saccharomyces cerevisiae
}

\author{
Claudio Saavedra, ${ }^{1}$ Kuei-Shu Tung, ${ }^{2,3}$ David C. Amberg, ${ }^{1,4}$ Anita K. Hopper, ${ }^{2}$ and Charles N. Cole ${ }^{1,5}$ \\ ${ }^{1}$ Department of Biochemistry, Dartmouth Medical School, Hanover, New Hampshire 0.3755 USA; ${ }^{2}$ Department of \\ Biochemistry and Molecular Biology, The Milton S. Hershey Medical Center, Pennsylvania State University, Hershey, \\ Pennsylvania 17033 USA
}

The response of eukaryotic cells to heat shock and other forms of stress occurs at both transcriptional and post-transcriptional levels. We used in situ hybridization to determine whether stress affected the subcellular distribution of poly $(\mathbf{A})^{+}$RNA in Saccharomyces cerevisiae. Following induction of stress by either heat shock $\left(42^{\circ} \mathrm{C}\right)$ or addition of a high concentration of ethanol $(10 \%)$, the nucleocytoplasmic export of most poly $(A)^{+}$ RNA was blocked. In situ hybridization indicated that heat-inducible SSA4 and SSA1 mRNAs were exported from nuclei under these same conditions. On the other hand, both GAL1 and URA3 transcripts expressed from the SSA4 promoter accumulated in nuclei following heat shock. Sequences within either the $5^{\prime} 1600$ or the 3' 500 nucleotides of SSA4 mRNA were sufficient to direct GAL1 mRNA to the cytoplasm during stress. The export of SSA4 mRNA following stress required functional nuclear pore complexes, as SSA4 mRNA accumulated in nuclei following heat shock of cells containing temperature-sensitive nucleoporins. However, the selective export of SSA4 mRNA was maintained in heat-shocked cells carrying temperature-sensitive alleles of RNA1, PRP20, or an inducible dominant-negative allele of GSP1, the $S$. cerevisiae homolog of RAN/TC4. The results reported here suggest that there is selective export of mRNA in yeast.

[Key Words: Nucleocytoplamic transport; heat shock; yeast; Ran/TC4; protein import; in situ hybridization]

Received April 4, 1996; accepted in revised form May 28, 1996.

In eukaryotic cells, the biogenesis of mature mRNA requires transcription and several post-transcriptional processing steps that occur within the nucleus before the mature mRNA is exported to the cytoplasm. These processing steps include addition of a cap at the $5^{\prime}$ end of the pre-mRNA, cleavage, addition of a poly $(A)$ tail at the $3^{\prime}$ end of the mRNA, and splicing to remove introns from the pre-mRNA. The presence of the 7-methyl-guanosine cap at the 5' end of the mRNA enhances mRNA export but is not required for the export of microinjected mRNA (Hamm and Mattai 1990). A 3'-end poly(A) tail may enhance mRNA export and probably helps to protect pre-mRNAs and mRNAs from nucleolytic degradation but is not an essential signal for mRNA export (Jarmolowski et al. 1994). Although transcribed sequences could contain export information, the protein components of hnRNPs are likely to contain signals for export of heterogenous nuclear ribonucleoprotein (hnRNP), as nuclear export signals have been defined for human hnRNP A1 (Michael et al. 1995) and the HIV-1 Rev protein (Fischer et al. 1995).

Several trans-acting components needed for efficient

Present addresses: ${ }^{3}$ Department of Biology, Yale University, New Haven, Connecticut 06510 USA; ${ }^{4}$ Department of Genetics, Stanford University Medical Center, Palo Alto, California 94305 USA.

${ }^{5}$ Corresponding author.
RNA export have been identified. The PRP2O/Clark and Sprague 1989; Vijayraghavan et al. 1989; Acbi et al. 1990) and RNA1 (Hartwell 1967; Hopper et al. 1978 / genes encode, respectively, a guanine-nucleotide exchange factor (for review, see Dasso 1993; Sazer 1996) and a GTPaseactivating protein (Becker et al. 1995; Bischoff ct al. 1995; Corbett et al. 1995) for Gsplp (Belhumeur et al. 19931, the yeast homolog of the mammalian RAN/TC4 protein. Poly $(\mathrm{A})^{+}$RNA accumulates in the nuclei of ycast and mammalian cells carrying temperature-sensitive mutations of PRP20 and RNA1 (Amberg et al. 1992, 1993; Forrester et al. 1992; Kadowaki et al. 1992l, and also in yeast cells overexpressing a dominant-negative form of Gsplp (Schlenstedt et al. 1995), suggesting that the Gspl GTPase cycle is involved in the export of mRNA from the nucleus. An additional important factor shown to be necessary for efficient mRNA nuclear export in budding yeast is Npl3p (Lee et al. 1996). Some of the structural features of $\mathrm{Npl} 3 \mathrm{p}$ are also found in some mammalian hnRNP proteins, including two RRM domains and a carboxy-terminal glycine-rich domain that contains RGGY/F repeats (for review, see Dreyfuss 1986). Moreover, Npl3p has been shown to shuttle between the nucleus and the cytoplasm (Bossie et al. 1992; Russell and Tollervey 1992; Flach et al. 1994; Wilson et al. 1994!.

During heat shock or other types of stress, cells redirect their synthetic machinery to produce several fami- 
lies of heat shock proteins. Redirection of the synthetic machinery occurs at multiple levels, including transcription, post-transcriptional RNA processing, and RNA turnover. In this study we report that heat shock and other forms of stress lead to the accumulation of poly $(\mathrm{A})^{+}$RNAs within yeast nuclei, whereas heat shock mRNAs SSA4 and SSA1 (encoding S. cerevisiae Hsp70) are efficiently exported to the cytoplasm. We examined the heat shock response in cells carrying mutant alleles of RNA1, PRP20, or GSP1 and observed that export of most poly $(\mathrm{A})^{+}$RNAs were blocked but export of SSA4 mRNA continued following cellular stress. Under the same conditions, however, SSA4 mRNA was retained in the nuclei of cells carrying temperature-sensitive mutants of nucleoporins RAT7/NUP159, RAT2/NUP120, and NUP145. These results indicate that selective export of heat shock mRNAs occurs following stress, requires functional NPCs, but does not require the RAN/GSP1 GTPase system. Cellular stress also inhibited nuclear protein import of a karyophilic reporter protein.

\section{Results}

Nucleocytoplasmic transport of poly $(A)^{+}$RNA is blocked following heat stress in yeast

We employed in situ hybridization to compare the subcellular distribution of poly $(\mathrm{A})^{+}$RNA in Saccharomyces cerevisiae under various conditions of growth or stress. This assay uses an oligo $(\mathrm{dT})_{50}$ probe to which digoxigenin-dUTP is added at its $3^{\prime}$ end (Amberg 1992). The sites at which this probe hybridizes to RNA are visualized by using an FITC-conjugated anti-digoxigenin antibody and fluorescence microscopy (Amberg et al. 1992). A typical pattern for cells growing exponentially at $23^{\circ} \mathrm{C}$ is shown in Figure 1A, and the same field of cells stained with DAPI, to permit visualization of the nuclei, is shown in Figure 1B. As expected, poly $(\mathrm{A})^{+}$RNA was distributed throughout the cell under conditions of normal growth. However, a strong nuclear accumulation of $\operatorname{poly}(\mathrm{A})^{+}$ RNA was seen in all cells after exposing wild-type cells to heat shock stress conditions $\left(42^{\circ} \mathrm{C}\right.$ or $\left.45^{\circ} \mathrm{C}\right)$ for $1 \mathrm{hr}$ (Fig. 1C). The accumulation of poly $(\mathrm{A})^{+}$RNA was detectable as soon as $5 \mathrm{~min}$ after heat shock and was prominent in nearly $100 \%$ of the cells within $30 \mathrm{~min}$ after heat shock (data not shown). Some poly(A) ${ }^{+}$RNA was detected in the cytoplasm following heat shock. Most likely, this represents cellular mRNAs that have not been degraded plus those mRNAs induced and exported from nuclei during cellular stress.

\section{Detection of single species transcripts in yeast: export of SSA4 (Hsp70) mRNA is not blocked following heat shock}

The heat shock response is regulated both transcriptionally and post-transcriptionally (Morimoto et al. 1994). Therefore, the observation that heat shock induced a block to mRNA export raises an intriguing paradox: How can a stress response be mounted if export of
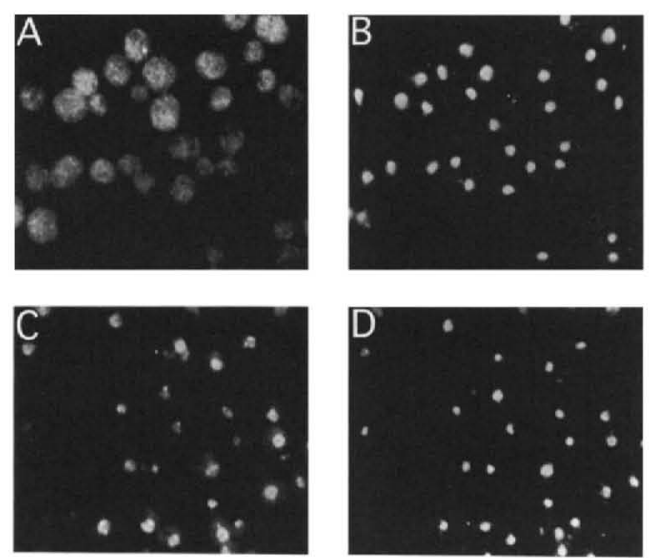

Figure 1. Poly $(\mathrm{A})^{+}$RNA accumulates in the nuclei of yeast cells shifted to $42^{\circ} \mathrm{C}$ for $1 \mathrm{hr}$. (A) In situ hybridization to detect poly $(A)^{-}$RNA of wild-type cells incubated at room temperature. $|B|$ DAPI-stained image of the same field of cells as in $\boldsymbol{A}$. $(C)$ In situ hybridization to detect poly|A $)^{+}$RNA in wild-type cells shifted to $42^{\circ} \mathrm{C}$ for $1 \mathrm{hr}$. (D) DAPI staining of the same field of cells as in $C$.

poly $(A)^{+}$RNA from the nucleus is blocked? Perhaps heat shock mRNAs can leave the nucleus by some mechanism while the bulk of poly $(A)^{+}$RNA would remain in the nucleus following stress. To address this possibility, we modified the in situ hybridization assay to permit detection of individual species of mRNA /see Materials and methods).

SSA4 is one of the four members of the yeast Hsp70SSA gene subfamily. It is expressed at an extremely low level during vegetative growth but is rapidly induced to a high level following heat shock (for review, see Craig 1992). Because of its induciblility, low basal level of expression, and thorough characterization (Boorstein and Craig 1990; Young and Craig 1993), we chose first to detect the SSA4 transcript. The DNA sequences of the four SSA genes are closely related, but the 3 '-untranslated region of SSA4 lacks significant identity with the other three $S S A$ genes. To obtain a probe specific for SSA4 mRNA, we employed PCR to generate a 270-bp DNA corresponding to the $3^{\prime}$ end of SSA 4 mRNA.

We introduced a $2 \mu$ plasmid containing the entire SSA4 gene into wild-type yeast cells. Northern analyses were used to compare the levels of SSA4 mRNA present under different conditions. There was little SSA4 mRNA under normal growth conditions, but it was induced rapidly by heat shock $\left(42^{\circ} \mathrm{C}\right)$ (Fig. $\left.2 \mathrm{~A}\right)$ and to higher levels than in wild-type cells that carry a single copy of SSA4 (data not shown). Unlike bulk poly $(A)^{+}$RNA, which was restricted to nuclei under these conditions, SSA4 mRNA was localized throughout the cell (Fig. 2B, panel C). Little or no fluorescent signal for SSA4 mRNA was observed in cultures grown at room temperature (Fig. 2B, panel A).

A similar nuclear accumulation of $\operatorname{poly}(\mathrm{A})^{+}$, along with induction and export of SSA4 mRNA, was also seen when wild-type yeast cells were stressed by the addition 

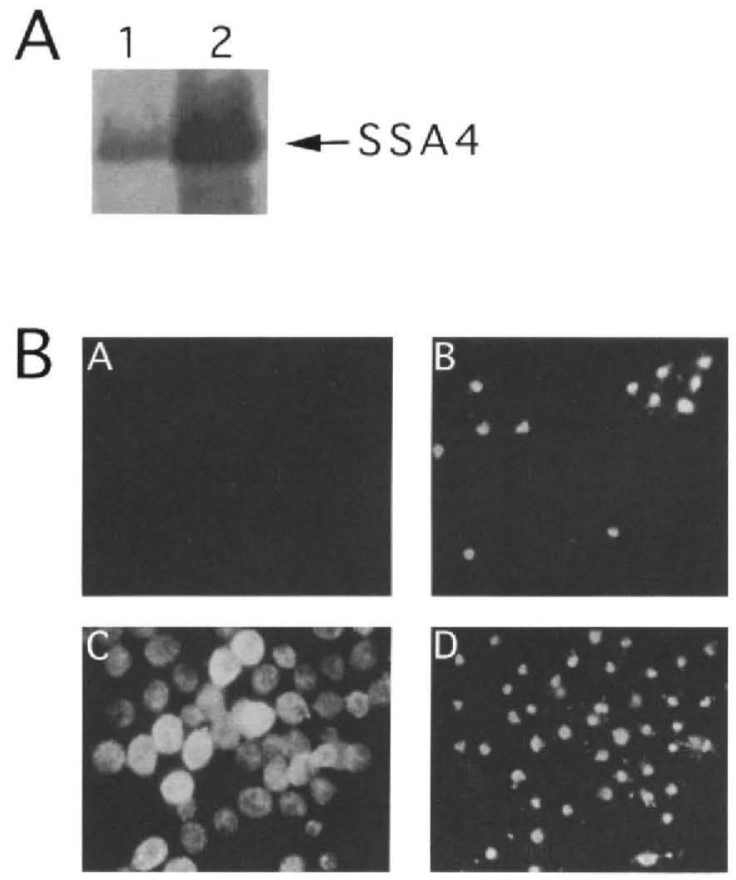

Figure 2. SSA4 mRNA is induced and appears in the cytoplasm following heat shock. (A) Northern blot detection of SSA4 mRNA in cells transformed with a high-copy plasmid (pEC702) containing the SSA4 gene. Total RNA was isolated from cells grown at $23^{\circ} \mathrm{C}$ (lane 1) or shifted to $42^{\circ} \mathrm{C}$ for $1 \mathrm{hr}$ (lane 2). (B, panel $A$ ) In situ hybridization detection of SSA4 mRNA in wildtype cells incubated at $23^{\circ} \mathrm{C}$. (Panel $B$ ) DAPI staining of the same field of cells as in panel $A$. (Panel $C$ ) In situ hybridization detection of SSA4 mRNA in wild-type yeast cells shifted to $42^{\circ} \mathrm{C}$ for $1 \mathrm{hr}$. (Panel D) DAPI staining of the same field of cells as in panel $C$.

of ethanol to a final concentration of $10 \%$ (data not shown). We also examined the nucleocytoplasmic distribution of SSA1 mRNA, encoding another member of the yeast $\mathrm{Hsp} 70$ family and found that this mRNA was also efficiently exported to the cytoplasm following either heat or ethanol shock (data not shown).

\section{Transcription from the SSA4 promoter is not sufficient for selective export of $m R N A s$ under its control}

The promoters of heat shock genes are primed for rapid response, as evidenced by their nuclease hypersensitivity (Wu 1980) and by the fact that the TATA box-binding protein and heat shock transcription factor are bound to the promoters of heat shock genes in the absence of heat shock (Gross et al. 1990, 1993; Giardina and Lis 1995a,b). This preloading of transcription factors onto the heat shock promoters appears to allow rapid initiation of transcription following stress. A scenario that could account for the differential subcellular localization of bulk poly $(\mathrm{A})^{+}$RNA and SSA4 mRNA would be that SSA4 transcription is activated prior to the onset of the block to export of poly $(\mathrm{A})^{+}$RNA that develops following heat stress. If this were the case, heat shock mRNAs would be synthesized and exported extremely rapidly after stress, whereas most mRNAs would progressively accumulate inside the nucleus during the heat treatment.

To address this scenario, we subcloned the GAL1-coding region downstream of the SSA4 promoter in a high copy plasmid, introduced the plasmid into wild-type yeast cells, and located the GAL1 transcripts by in situ hybridization (Fig. 3). The SSA4 promoter fragment used for this construct extends from nucleotide -1200 to -40 relative to the GAL1 transcription initiation site. This fragment contains the TATA box and five canonical heat shock consensus sequences (Fig. 3B).

Upon shifting the cultures from $23^{\circ} \mathrm{C}$ to $42^{\circ} \mathrm{C}$ for $1 \mathrm{hr}$,
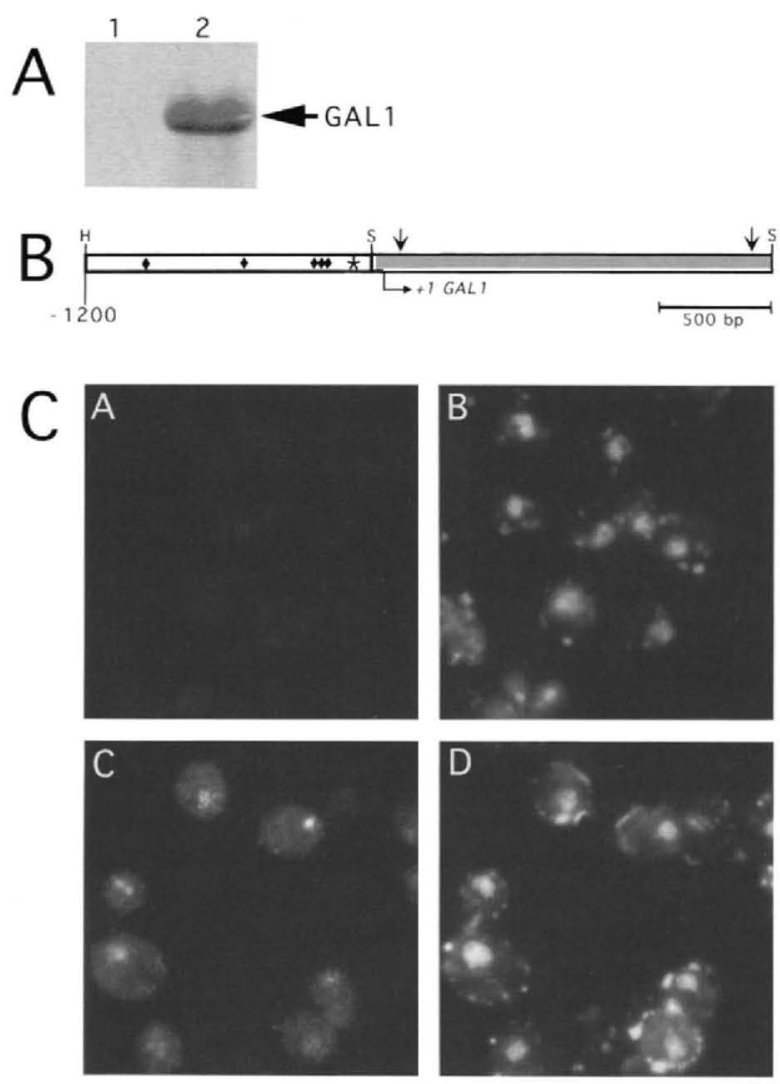

Figure 3. GAL1 mRNA is retained in nuclei following heat shock. Wild-type cells harboring a high-copy plasmid containing GAL1 sequences under control of the SSA4 promoter were either incubated at $23^{\circ} \mathrm{C}$ or shifted to $42^{\circ} \mathrm{C}$ for $1 \mathrm{hr}$. $|A|$ Northern blot detection of GAL1 mRNA. Total RNA was isolated from cells either grown at $23^{\circ} \mathrm{C}$ (lane 1 ) or shifted to $42^{\circ} \mathrm{C}$ for $1 \mathrm{hr}$ (lane 2). (B) Diagram of the GAL1 construct. Dark area represents the GAL1 sequences. Vertical arrows show beginning and end of the open reading frame. The open area represents the SSA4 promoter. Black diamonds show the canonical heat shock elements; the asterisk shows TATA box at -80 . (H) HindIII; (S) Stul sites. (C, panel $A$ ) In situ hybridization to detect GAL1 mRNA in cells grown at $23^{\circ} \mathrm{C}$. (Panel $\left.B\right)$ DAPI staining of the same field of cells as in panel $A$. (Panel $C)$ In situ hybridization to detect GAL1 mRNAs in cells shifted to $42^{\circ} \mathrm{C}$ for $1 \mathrm{hr}$. (Panel $D$ ) DAPI staining of the same field of cells as in panel $C$. 
this hybrid gene was readily induced (Fig. 3C). The subcellular distribution of the GAL1 mRNA was determined by in situ hybridization /see Materials and methods). No signal for GAL1 mRNA was evident in cells maintained at $23^{\circ} \mathrm{C}$ (Fig. $3 \mathrm{C}$, panel A). After heat treatment at $42^{\circ} \mathrm{C}$, this mRNA (Fig. $3 \mathrm{C}$, panel $\mathrm{C}$ ) accumulated in the nucleus although some was also detected in the cytoplasm. This indicates that the SSA4 promoter functioned normally and was induced strongly by heat shock. We also found that a URA3 mRNA under control of the same SSA4 promoter accumulated in nuclei under the same stress conditions (data not shown). Therefore, the promoter of the SSA4 gene and its rapid induction by stress are not sufficient to account for the selective export of an mRNA produced under its control.

If cytoplasmic accumulation of SSA4 mRNA were attributable solely to rapid transcription of $S S A 4$ prior to the onset of the block in export of poly $\mid \mathrm{A})^{+}$RNA, the SSA4 mRNA should be transcribed only very early following stress. By this scenario, continued transcription of the $S S A 4$ gene once the block to export of poly $\mid \mathrm{A})^{+}$ RNA had developed would be expected to result in nuclear accumulation of SSA4 mRNA. Therefore, we examined the kinetics of SSA4 mRNA induction in heatshocked $\left(42^{\circ} \mathrm{C}\right)$ yeast cells (Fig. 4). SSA4 RNA was virtually undetectable prior to heat shock but was easily detected within $5 \mathrm{~min}$ after shifting to $42^{\circ} \mathrm{C}$. SSA 4 mRNA synthesis continued and reached a maximum at 30 min after the initial heat shock, at which time accumulation of poly $(\mathrm{A})^{+}$RNA in the nucleus was readily detected. Subsequently, the levels of SSA4 mRNA declined. These data suggest that the appearance of SSA4 mRNA in the cytoplasm following heat shock, and the retention in the nucleus of poly $(\mathrm{A})^{+}$RNA, reflect selective export of the SSA4 mRNA rather than extremely rapid induction of its promoter prior to the establishment of a block to export of poly $(A)^{+}$RNA.

Sequences within the $3^{\prime}$-terminal 500 nucleotides of the SSA4 transcript facilitate export of a heterologous coding region following heat shock

To study whether the SSA4 mRNA contains sequences

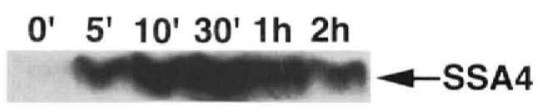

Figure 4. Northern analysis of the kinetics of accumulation of SSA4 mRNA following heat shock. Wild-type yeast cells in the exponential phase of growth were shifted from $23^{\circ} \mathrm{C}$ to $42^{\circ} \mathrm{C}$. Samples of cells were harvested at the time of the shift $(0 \mathrm{~min})$ and at various times after the shift to $42^{\circ} \mathrm{C}$. RNA was isolated from cells and subjected to electrophoresis in an agarose gel. A Northern blot was prepared and probed with a digoxigenin-labeled probe for SSA4 mRNA. (Lane 1) RNA from cells harvested at the time of the shift to $42^{\circ} \mathrm{C}$ ); (lanes 2-6) RNAs harvested at $5,15,30,60$, and $120 \mathrm{~min}$ after the shift.
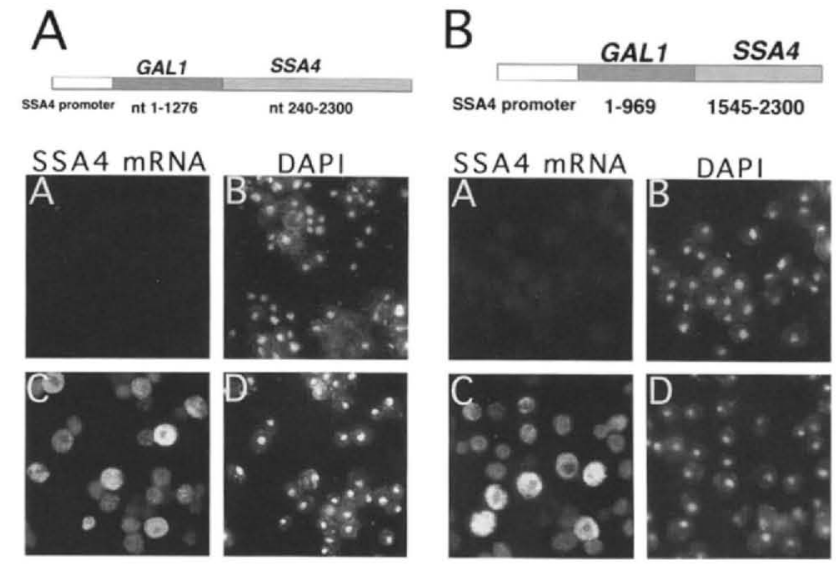

Figure 5. Hybrid GAL1-SSA4 mRNAs are exported from the nucleus following heat shock. Hybrid constructs on a high-copy plasmid $(2 \mu$-derived) were prepared that contained both GAL1 and SSA 4 sequences, expressed from the SSA4 promoter. $(A)$ The hybrid gene contains nucleotides 1-1276 of GAL1 upstream of SSA4 sequences 240-2300, including the 3'-end signals. (B) 1612 nucleotides were deleted from the construct examined in $A$ to yield a construct containing nucleotides 1-969 of GAL1 and nucleotides 1545-2300 of SSA4. Within each half of $A$ and $B$, panels $A$ show in situ hybridization to detect the hybrid GAL1-SSA4 mRNA in cells cultured at $23^{\circ} \mathrm{C}$. The probe used is specific for SSA4 sequences and is the same probe used for Fig. 2. Panels $B$ show DAPI staining of the same fields of cells shown in panels $A$. Panels $C$ show in situ hybridization to detect the GAL1-SSA4 hybrid mRNA in cells shifted to $42^{\circ} \mathrm{C}$ for $1 \mathrm{hr}$. Panels $D$ show DAPI staining of the same fields of cells shown in panels $C$.

that facilitate its differential export during heat shock or whether it lacks sequences that promote nuclear retention of most mRNAs during stress, we constructed in a high-copy plasmid a GAL1-SSA4 hybrid gene whose transcription was driven by the SSA4 promoter. The fusion transcript consisted of the GAL1-coding region (1276 nucleotides) minus polyadenylation and transcription termination sequences, followed by most of the SSA4-coding region ( $2060 \mathrm{bp}$ ) including its polyadenylation and transcription termination signals (Fig. 5A). When the strain carrying this plasmid was shifted to $42^{\circ} \mathrm{C}$ for $1 \mathrm{hr}$, in situ hybridization revealed that the hybrid RNA was located throughout the cell (Fig. 5A, panel C). The same staining pattern was seen using either GAL1-specific or SSA4-specific probes, as the hybrid mRNA contains sequences complementary to both / data not shown). These results indicate that in this situation, nuclear export is dominant over retention and that SSA4 mRNA may possess sequences that facilitate export. The signal intensity varied considerably from cell to cell (see Fig. $5 \mathrm{~A}$, panel C). This most likely reflects the wide range of plasmid copy numbers in different cells and may also indicate that transcription of the SSA4 promoter is not induced equally in all cells.

Because SSA 4 sequences were necessary and sufficient to mediate export following heat shock when fused to a 
heterologous mRNA that otherwise was retained in the nucleus, we created progressive deletions of the SSA4coding region to identify the SSA4 sequences involved in export. We began with the GAL1-SSA4 hybrid gene described above and deleted $S S A 4$ sequences progressively toward the $3^{\prime}$ end of the SSA 4 sequences. We were able to remove most of the SSA4 sequences without significantly affecting the ability of the hybrid transcript to be exported to the cytoplasm following heat shock. The construct containing the smallest amount of SSA4 is diagrammed in Figure $5 \mathrm{~B}$, and the localization of all GAL1 $S S A 4$ hybrid transcript produced from this construct in cells shifted to $42^{\circ} \mathrm{C}$ for $1 \mathrm{hr}$ is shown in Figure $5 \mathrm{~B}$, panel C. Thus, selective export still occurred in a hybrid transcript containing only those SSA4 sequences derived from the very end of the coding region and extending through to the $3^{\prime}$ end of the SSA4 mRNA.

We also prepared a fusion construct in which the SSA4 promoter directs production of a hybrid mRNA consisting of the first 1680 nucleotides of SSA4 mRNA and nucleotides 650-1753 of GAL1 mRNA, including its signals for 3 '-end processing and polyadenylation. The mRNA from this construct was detected primarily in the cytoplasm following heat shock (data not shown), indicating that SSA4 mRNA contains multiple sequences that facilitate cytoplasmic accumulation of SSA4 mRNA following heat shock.

Selective export of SSA4 $M R N A$ occurs in yeast strains carrying mutant alleles of the RNAl, PRP20, or GSPI genes

The yeast small GTPases Gsplp and Gsp2p (homologs of mammalian Ran/TC4) (Belhumeur et al. 1993), the
GTPase activating protein encoded by RNA1 (Atkinson et al. 1985; Becker et al. 1995; Bischoff et al. 1995; Corbett et al. 19951, and the guanine nucleotide exchange factor encoded by PRP20 (Aebi et al. 1990) all are important for import of proteins into nuclei. The export of poly $(A)^{+}$RNA from the nucleus to the cytoplasm is also blocked in yeast strains carrying mutant alleles of these genes (Amberg et al. 1992, 1993; Forrester et al. 1992; Kadowaki et al. 1992; Melchior et al. 1993; Moore and Blobel 1993; Corbett et al. 1995; Schlenstedt et al. 1995). Because the export of heat shock mRNAs responded differently to stress signals than did the bulk of cellular mRNAs, we tested whether export was dependent on or independent of the Ran/TC4 GTPase system.

Previous studies reported conflicting data concerning the production of heat shock proteins in rna1-1 cells under temperature conditions $\left(37^{\circ} \mathrm{C}\right)$ that we now know prevent export from the nucleus of most poly $(\mathrm{A})^{+}$RNAs (McAlister and Finkelstein 1980; Miller et al. 1982; Amberg et al. 1992). We have confirmed the data of Miller et al. (1982) and expanded these studies. We found that heat shock mRNAs were transcribed, processed, exported from the nucleus, and translated into heat shock proteins in cells carrying mutant alleles of GSP1, PRP20, and $R N A 1$. We prepared extracts from ${ }^{35} \mathrm{~S}$-labeled wildtype and mutant cells either incubated continuously at $23^{\circ} \mathrm{C}$ or shifted to $34^{\circ} \mathrm{C}$ (Fig. $6 \mathrm{~A}$ ), $37^{\circ} \mathrm{C}$ (Fig. $6 \mathrm{~B}$ ), or $41.5^{\circ} \mathrm{C}$ (Fig. 6C) for various periods of time. In all cases, proteins were labeled for $15 \mathrm{~min}$ beginning at the times indicated in Figure 6.

In wild-type cells, heat shock proteins were synthesized transiently in cells shifted to $34^{\circ} \mathrm{C}$ or $37^{\circ} \mathrm{C}$ for 15 min but were no longer synthesized at substantial levels $1 \mathrm{hr}$ following the temperature shift (Fig. 6A,B). A sus-
A
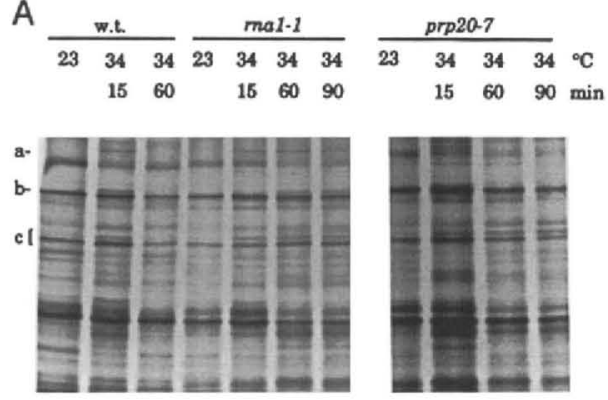

B
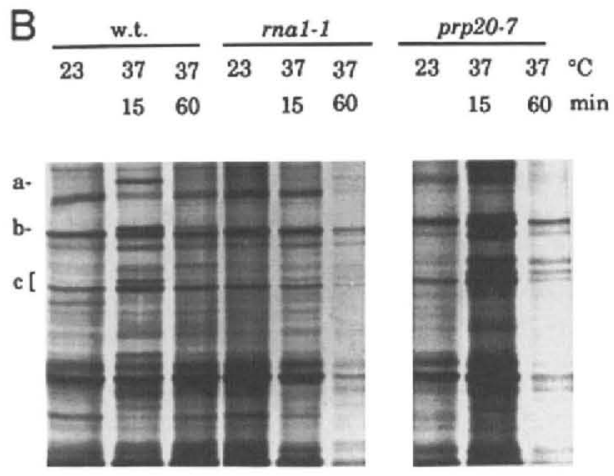

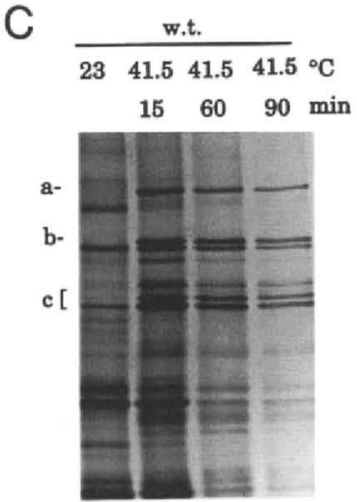

Figure 6. Analysis of heat shock protein synthesis. Assessment of total protein synthesis in strains EElb-35 (wild type), EElb (rna1-1), and M3161 A (prp20.7) after heat shock at $34^{\circ} \mathrm{C}(A)$, $37^{\circ} \mathrm{C}(B)$, or $\left.41.5^{\circ} \mathrm{C} \mid \mathrm{C}\right)$. Cells were grown at $23^{\circ} \mathrm{C}$ or were shifted to elevated temperatures for 15 , 60 , or $90 \mathrm{~min}$, as indicated above each lane, and ${ }^{35} \mathrm{~S} \mid$ methionine was added. After a 15 -min labeling period, cell extracts were prepared, and the proteins were resolved by SDS-polyacrylamide gel electrophoresis and detected by autoradiography. Particular heat shock proteins are indicated by lowercase letters at the left of each panel. $(a)$ Hsp104, $|b| \mathrm{Hsp90;}(c)$ Hsp70s. For extracts prepared from cells shifted to $34^{\circ} \mathrm{C}, 3.3$ times more final extract from EE 1 b cells was loaded compared to EE 1 b- 35 cells. For extracts prepared from cells shifted to $37^{\circ} \mathrm{C}$, the autoradiograph of EElb was exposed eight times longer than that for EElb-35. The autoradiograph of the extracts prepared from prp20-7 cells shifted to $37^{\circ} \mathrm{C}$ was exposed 14 times longer than the one for $34^{\circ} \mathrm{C}$. 
tained heat shock response in wild-type cells required a shift to $41.5^{\circ} \mathrm{C}$. Within $15 \mathrm{~min}$ of the temperature shift, heat shock proteins were the most abundant labeled proteins, and this predominance was even greater when cells were labeled $60 \mathrm{~min}$ after a shift. This is the expected result wherein a mild stress induces a transient heat shock response followed by recovery and more severe stress induces a sustained heat shock response (Lindquist 1986).

In rna1-1 and prp20-7 mutant strains, lower levels of protein synthesis occurred following temperature shift. This most likely reflects the dramatic inhibition of protein import, RNA processing, and RNA export that occur at elevated temperatures. We compensated for this either by loading a greater amount of extract or exposing the autoradiograph for a longer period of time (see legend to Fig. 6). In rna1-1 cells shifted to $34^{\circ} \mathrm{C}$ or $37^{\circ} \mathrm{C}$ (rna1-1 cells do not grow at temperatures exceeding $30^{\circ} \mathrm{C}$ ), heat shock proteins were detectable in cells labeled following a 15-min temperature shift (Fig. 6A,B). The pattern seen was similar to that seen in wild-type cells. However, whereas inducible heat shock proteins were not synthesized at detectable levels in wild-type cells shifted for 60 min or longer, their synthesis continued in ma1-1 and prp20-7 cells 60 and $90 \mathrm{~min}$ after the temperature shift. Although the amount of protein synthesized in rna1-1 or prp20-7 cells was dramatically reduced $60 \mathrm{~min}$ after a shift, the pattern was very similar to that seen in wildtype cells heat-shocked at $41.5^{\circ} \mathrm{C}$ for 60 or $90 \mathrm{~min}$ (Fig. 6 , cf. B with Cl. Thus, the rna1-1 and prp20-7 cells mounted a sustained heat shock response at temperatures that led to a transient response in wild-type cells.

Northern analysis was used to compare the induction of SSA4 mRNA following heat shock in wild-type cells and in the rna1-1 mutant strain (Fig. 7). Most mRNAs fail to accumulate in rna1-1 cells, and those that do accumulate are often of an aberrantly large size (Shiokawa and Pogo 1974; Atkinson et al. 1985; Traglia et al. 1989; Forrester et al. 1992). In wild-type cells, as expected, there was a modest induction of SSA4 RNA following a 15 -min shift of wild-type cells to $34^{\circ} \mathrm{C}$. This induction was transient, with the level dropping to just above the basal level within $60 \mathrm{~min}$. Stronger induction occurred

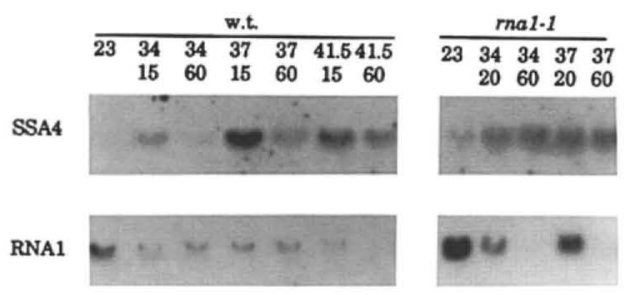

Figure 7. Northern analysis of RNA1 and SSA4 mRNAs. Total RNA was extracted from EE1b-35 (wild type) (lanes 1-7) or EElb (rna1-1) (lanes 8-12). The temperature and time of incubation for each culture before RNA extraction are indicated. The blots were hybridized with end-labeled oligonucleotide probes for SSA4 transcripts or with a random primer-labeled RNA1-specific probe.
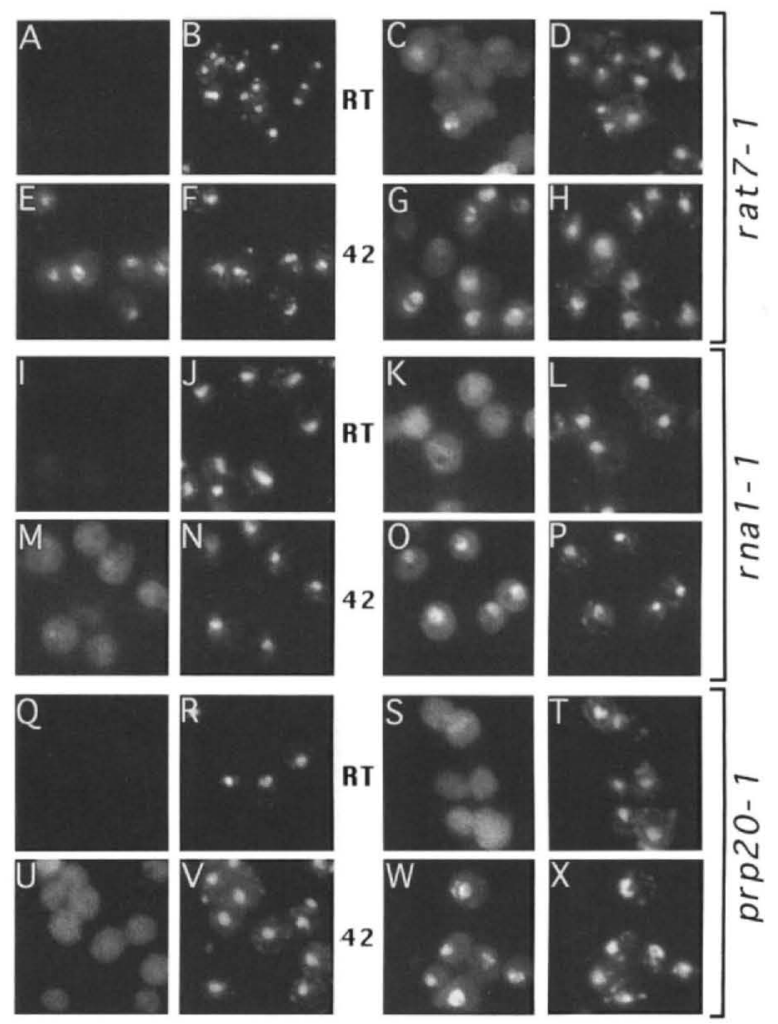

Figure 8. In situ hybridization assessment of SSA4 mRNA export following heat shock in rat 7-1, ma1-1, and prp20-1 strains. For each strain, eight panels are shown. The top four represent images from cells incubated continuously at $23^{\circ} \mathrm{C}$. The bottom four represent images from cells shifted to $42^{\circ} \mathrm{C}$ for $1 \mathrm{hr}$. In all cases, DAPI staining of the same fields of cells as those showing $S S A 4$ RNA $(A, E, I, M, Q, U)$ or poly $(\mathrm{A})^{+}$RNA $(C, G, K, O, S, W)$ are shown.

following a 15-min shift of wild-type cells to $37^{\circ} \mathrm{C}$, and again, the level dropped substantially by $1 \mathrm{hr}$ after temperature shift. The level of SSA4 mRNA dropped more slowly from its maximum following a shift of wild-type cells to $41.5^{\circ} \mathrm{C}$. In the ma1-1 strain, the level of SSA4 mRNA was induced to similar levels by a shift to $34^{\circ} \mathrm{C}$ or $37^{\circ} \mathrm{C}$. In contrast to wild-type cells, in ma1-1 cells, the induction of SSA4 mRNA was sustained for at least $\mathrm{l} \mathrm{hr}$. Thus, SSA4 mRNA did accumulate in rna1-1 cells and did not appear to be of an aberrant size (Fig. 7).

The subcellular distribution of poly $(\mathrm{A})^{+}$RNA and SSA4 mRNA in heat shocked ma1-1 and prp20-1 cells was examined. We also examined the heat shock response in rat 7-1 cells, which carry a temperature-sensitive allele of the RAT7/NUP159 gene, encoding the Rat7p/Nup159p nucleoporin (Gorsch et al. 1995). Shifting rat7-1 cells to the nonpermissive temperature of $37^{\circ} \mathrm{C}$ results in a rapid block to export of poly $(\mathrm{A})^{+} \mathrm{RNA}$ (Gorsch et al. 1995). Cultures of exponentially growing cells were shifted to $42^{\circ} \mathrm{C}$ for $1 \mathrm{hr}$ and then processed for in situ hybridization. In all three cases (rna1-1, prp20-1, and rat7-1), poly $(\mathrm{A})^{+}$RNA accumulated in nuclei in heat-shocked cells (Fig. 8G, O,W). Following heat shock, 


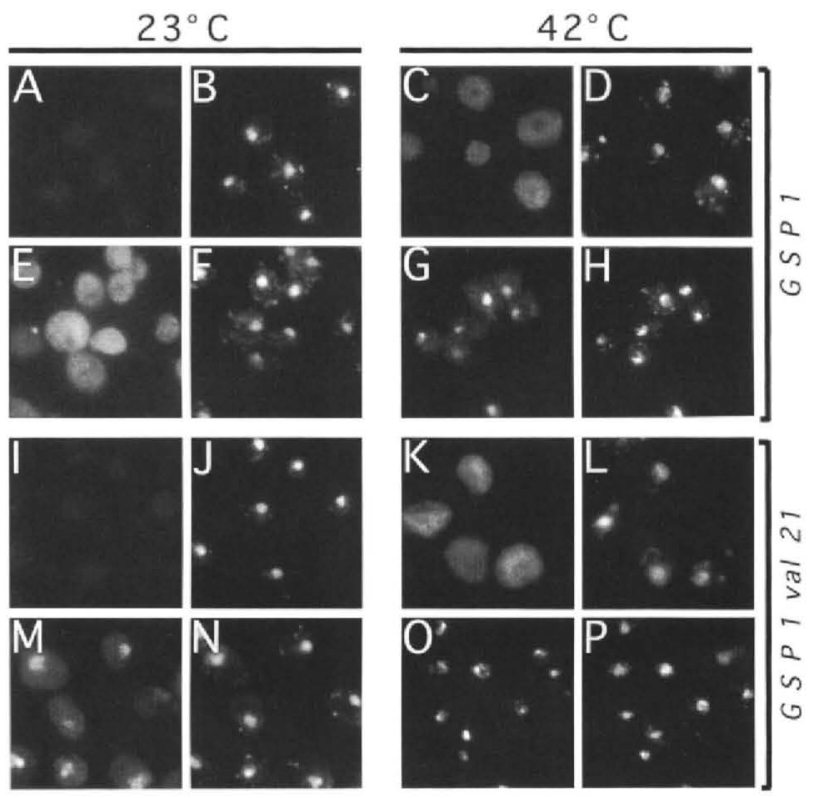

Figure 9. In situ hybridization assessment of SSA4 mRNA export following heat shock in wild-type cells containing a galactose-inducible GSP1 gene or a dominant-negative (GSP1 ${ }^{\text {'ot }}$ ) GSP1 allele. Wild-type cells (FY86) were transformed with YEpSSA4 and with either pGSPl (wild type $\mid(A-H)$ or pGSPl val21 (dominant negative) $(I-P)$. Cells were grown overnight in media containing $2 \%$ raffinose and were diluted and induced with $2 \%$ galactose during early exponential growth. After $3 \mathrm{hr}$, cells were shifted to $42^{\circ} \mathrm{C}$ for $1 \mathrm{hr}$. $(A, I)$ Localization of SSA4 mRNA in cells incubated at $23^{\circ} \mathrm{C} .(B, I)$ DAPI staining of the same fields of cells shown in $A$ and $I$, respectively. $(C, K)$ Localization of SSA4 mRNA in cells shifted to $42^{\circ} \mathrm{C}$. $(D, L)$ DAPI staining of the same fields of cells shown in $C$ and $K$, respectively. $(E, M)$ Localization of poly $(\mathrm{A})^{+}$RNA in cells incubated at $23^{\circ} \mathrm{C} .(F, N)$ DAPI staining of the same fields of cells shown in $E$ and $M$, respectively. $\{G . O\}$ Localization of poly $\mid \mathrm{A})^{+}$RNA in cells shifted to $42^{\circ} \mathrm{C} .\langle H, P\rangle$ DAPI staining of the same fields of cells shown in $G$ and $O$, respectively.

SSA4 mRNA was found in the cytoplasm of wild-type cells (data not shown) and accumulated in the nuclei of rat 7-1 cells (Fig. 8E). This indicates that export of SSA4 mRNA depends on the presence of functional Rat $7 \mathrm{p} /$ Nup159p and, presumably, functional nuclear pores. We also found that both poly $\mid \mathrm{A})^{+}$RNA and SSA4 mRNA were retained in the nuclei of cells carrying temperaturesensitive alleles of nucleoporins RAT2/NUP120 and NUP145 (data not shown). For rna1-1 cells (Fig. 8M) and prp20-1 cells (Fig. 8U), SSA4 was induced and SSA4 mRNA was distributed throughout the cells. Some accumulation of SSA4 mRNA in nuclei of heat-shocked prp20-1 and rna1-1 cells was also detected, and we believe this represents SSA4 mRNA bound to fragments of disrupted nucleoli. Although the PRP2O and RNA1 gene products are needed for export of poly $(\mathrm{A})^{+} \mathrm{RNA}$ from the nucleus, they do not appear to be required for the accumulation of SSA4 mRNA in the cytoplasm of heat shocked cells.

The distribution of poly $(\mathrm{A})^{+}$RNA and $S S A 4$ mRNA in heat-shocked cells overexpressing either wild-type Gsplp or a dominant-negative form of Gsplp/the G21V mutation/ was also examined. Induction of the mutant form of Gsplp (but not the wild-type form) leads to a dramatic block to the export of poly $(\mathrm{A})^{+}$RNA (Schlenstedt et al. 1995). Plasmids encoding either wild-type Gsplp or the dominant-negative mutant Gsplp under control of the GAL1 promoter were introduced into wild-type cells (FY23). Induction of wild-type Gsplp did not lead to accumulation of $\operatorname{poly}(\mathrm{A})^{+}$RNA in nuclei (Fig. 9E) nor to the induction of SSA4 mRNA (Fig. 9A). Induction of overexpression of the mutant form of Gsplp led to a dramatic accumulation of poly $(\mathrm{A})^{+} \mathrm{RNA}$ in nuclei (Fig. 9M), but little or no induction of SSA4 mRNA occurred (Fig. 9I). When cells that had been overexpressing wild-type Gsplp for $3 \mathrm{hr}$ were heat shocked, poly $(\mathrm{A})^{+}$ RNA still accumulated in nuclei (Fig. 9G) while SSA4 mRNA was detected primarily in the cytoplasm (Fig. 9C). In cells overexpressing the mutant form of Gsplp, poly $(\mathrm{A})^{+} \mathrm{RNA}$ was also found mainly in nuclei after heat shock (Fig. 9O) and SSA4 mRNA was detected predominantly in the cytoplasm (Fig. 9K). Taken together, these data suggest that the selective export of SSA4 mRNA following heat shock does not require Rnalp or Prp20p and that the dominant-negative form of Gsplp, which blocks both nuclear protein import and RNA export of bulk poly $\mid A)^{+}$RNA, does not interfere with export of SSA4 mRNA.

\section{Protein import is rapidly inhibited following cellular stress}

We analyzed the in vivo subcellular distribution of a green fluorescent protein $(\mathrm{GFP})$ derivative containing a nuclear localization signal (NLS). Although this protein was readily imported into nuclei in unstressed cells (Fig. 10), it accumulated rapidly in the cytoplasm of cells shifted to $42^{\circ} \mathrm{C}$. Eight minutes after shifting, $50 \%$ of the cells showed cytoplasmic fluorescence. At $12 \mathrm{~min}$ after shifting, the GFP-NLS reporter was predominantly cytoplasmic in $>90 \%$ of the cells. Addition of cycloheximide to cells at the time of shifting to $42^{\circ} \mathrm{C}$ did not alter the fluorescence distribution nor its signal intensity. Because the reporter protein in this GFP construct is sufficiently small to diffuse out of nuclei $(\sim 45 \mathrm{kD})$, the fluorescent signal seen in Figure 10 reflects primarily reporter protein made prior to the time when cells were shifted to $42^{\circ} \mathrm{C}$. We conclude that heat shock leads to an inhibition of nuclear protein import, but it does not affect protein diffusion out of the nucleus.

\section{Discussion}

When cells are exposed to higher than normal growth temperatures, the heat shock response is induced. This response is nearly universal, but different organisms display differences in the levels of regulation of the response and its duration (for review, see Lindquist 1986; Lindquist and Craig 1988). In most organisms this response is transient at moderate temperatures, with 


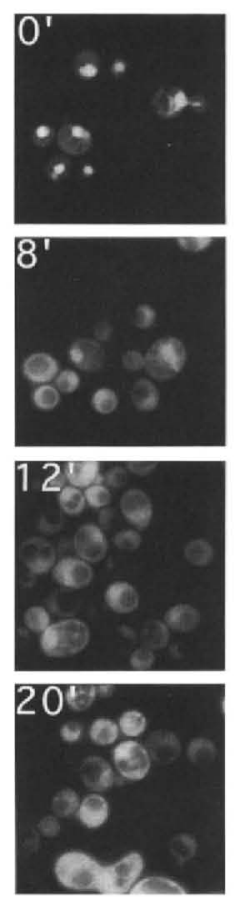

Figure 10. Nuclear protein import is inhibited by cellular stress. In vivo fluorescence to examine the subcellular distribution of the karyophilic reporter protein derived from GFP following heat shock. $\left(t=0^{\prime}\right)$ The GFP localization at the time of shift $(0 \mathrm{~min})$ to $42^{\circ} \mathrm{C}$. $\left(t=8^{\prime}, 12^{\prime}\right.$, and $\left.20^{\prime}\right)$ GFP localization at 8 , 12 , and $20 \mathrm{~min}$ after shifting to $42^{\circ} \mathrm{C}$, respectively.

growth resuming after a temporary pause, and the response is sustained at higher temperatures, until cells begin to die slowly (Lindquist 1986). The heat shock response consists of the induction of a group of highly conserved proteins, the heat shock or stress proteins. Conversely, the synthesis of many other proteins is decreased during the heat shock response. In S. cerevisiae, for example, a survey of the response of $\sim 500$ proteins to a temperature upshift showed 80 proteins to be induced or elevated, 20 to a high level, and $>300$ to be reduced (Miller et al. 1982)

Decrease in the production of non-heat-shock proteins can result from various mechanisms. For example, for some Drosophila mRNAs, this occurs via transcriptional repression (Ashburner and Bonner 1979). However, many studies in mammalian cells, Drosophila, Arabadopsis, and yeast have also implicated post-transcriptional mechanisms (Yost and Lindquist 1986, 1991; Bond 1988; Sadis et al. 1988; Shukla et al. 1990; Yost et al. 1990; Osteryoung et al. 1993). Pre-mRNA splicing, pre-rRNA processing, poly(A) tail length, nuclear RNA stability, and/or nuclear exit have all been reported to be affected by heat shock. For yeast, the splicing of pre-mRNA encoding actin is blocked by heat shock (Yost and Lindquist 1991), but the mRNA encoding a GTP-binding protein and several mRNAs encoding ribosomal proteins fail to accumulate upon heat shock and therefore are affected either at transcriptional or RNA turnover steps
(Herruer et al. 1988; Yost and Lindquist 1991). We have examined how heat shock affects the levels of GAL1 and SSA4 mRNA and find that the half-life of GAL1 mRNA was reduced from $\sim 20 \mathrm{~min}$ to $\sim 10 \mathrm{~min}$ following a shift to $42^{\circ} \mathrm{C}$, whereas the stability of $S S A 4$ was largely unaffected by heat shock (data not shown).

\section{Selective nucleocytoplasmic export of $m R N A$ following stress}

The studies described in this paper provide evidence that nucleocytoplasmic export is regulated as part of the heat shock response in $S$. cerevisiae. Following heat shock (Amberg 1992) or ethanol-induced stress, poly(A) ${ }^{+}$ RNAs accumulated within the nucleus. A recent report indicates that nuclear accumulation of $\operatorname{poly}(\mathrm{A})^{+}$RNA also occurs in Schizosaccharomyces pombe following heat shock (Tani et al. 1995). In contrast, in situ hybridization indicated that SSA4 mRNA was exported efficiently and accumulated to high levels in the cytoplasm of heat shocked S. cerevisiae cells.

In some organisms, including D. melanogaster, transcriptional induction of heat shock genes occurs very rapidly after heat shock, owing at least in part to the fact that RNA polymerase is found in a paused complex on heat shock genes $\left(\mathrm{O}^{\prime}\right.$ Brien and Lis 1991, 1993). Heat shock transcription factor directs the assembly of the transcriptional machinery on heat shock genes and that RNA polymerase becomes arrested following the formation of the first phosphodiester bonds, where it is poised for extremely rapid transcriptional elongation upon stress (Rasmussen and Lis 1993; Giardina and Lis 1995a,b). It is not known whether similar complexes exist in S. cerevisiae, but if they do, this could lead to induction of heat shock transcription sufficiently rapidly that a considerable amount of SSA4 mRNA might be produced and exported prior to the establishment of a block to nucleocytoplasmic export of poly(A) ${ }^{+}$RNA.

We think this rapid induction prior to a block in mRNA export is unlikely to explain the results we have obtained for two reasons. First, when the mRNAs for GAL1 and URA3 were expressed from the wild-type SSA4 promoter, each accumulated in nuclei following heat shock (Fig. 3B; data not shown). The kinetics of transcriptional induction of these constructs should be very similar to those for the complete SSA4 gene, yet the pattern of in situ hybridization seen with the SSA4driven GAL1 mRNA was very different from that seen for SSA4 RNA (cf. Figs. 2 and 3B). Second, we could detect nuclear accumulation of $\operatorname{poly}(\mathrm{A})^{+}$RNA within 5 min of heat shock. The nuclear signal for poly $(\mathrm{A})^{+}$RNA was strong within $30 \mathrm{~min}$, a time at which SSA4 mRNA was continuing to accumulate (Fig. 4).

Could changes in mRNA stability following stress explain the patterns of mRNA distribution described in these studies? If this were a significant factor in our experiments, one would not expect strong nuclear accumulation of poly $(\mathrm{A})^{+}$RNA in wild-type cells subjected to heat shock (Fig. 1) nor cytoplasmic accumulation of SSA4 mRNA in mutant strains (ma1-1, prp20-1, or 
GSP1 ${ }^{\text {val21 }}$ (Fig. 8) shown previously to have defects in the export of mRNA. Although some changes in mRNA stability certainly occur and affect the absolute levels of many mRNAs following stress, the most likely consequence of these changes in our experiments is to accelerate the decrease in the cytoplasmic signal for poly $(A)^{+}$ RNA following heat shock. Therefore, the patterns seen are not consistent with a major contribution from altered mRNA stabilities.

In an attempt to begin to define where within SSA4 mRNA signals for export are located, we deleted progressively beginning at the $5^{\prime}$ end of the SSA4 mRNA. We mapped a region sufficient to permit cytoplasmic export and accumulation of mRNAs containing it following stress to the 3' 500 nucleotides of SSA4 mRNA. However, there appear to be multiple signals for selective export with SSA4 mRNA, as another fusion, containing only the $5^{\prime} 1620$ nucleotides of SSA4, was also detected primarily in the cytoplasm following heat shock.

\section{Possible mechanisms of selective export}

Our data support the idea that heat shock mRNAs contain sequences or structures that are signals for export of these mRNAs under conditions where most mRNA export is blocked. These signals could interact directly with the RNA export machinery, or alternatively, they could bind a protein that itself would interact with the RNA export machinery. It was reported recently that nuclear export signals exist in two RNA-binding proteins, hnRNP Al and HIV-1 Rev (Fischer et al. 1995; Michael et al. 1995). Because these (and other) RNAbinding proteins shuttle rapidly between the nucleus and the cytoplasm (Piñol-Roma and Dreyfuss 1992; Flach et al. 1994; Meyer and Malim 1994), their nuclear export signals may play an important role in the export of the RNAs to which they bind. Most hnRNP proteins are highly abundant (for review, see Dreyfuss et al. 1993); an RNA-binding protein involved in export of heat shock mRNAs might be comparatively rare, and the spectrum of RNAs to which it bound could determine which mRNAs were exported under heat shock conditions. Just as the HIV-1 Rev protein appears to target an export pathway different from that for export of poly $(A)^{+}$RNA (Fischer et al. 1995), a protein that bound heat shock mRNAs could target them to a different export pathway from that used by mRNA, thus permitting their export under conditions the lead to nuclear accumulation of most mRNAs. A related possibility is that these sequences act to override a stress-induced block in maturation of mRNA or its packaging into exportable hnRNP. Future studies will be directed at determining the precise mechanism of selective export.

As expected, we found that export of SSA 4 mRNA did not occur following heat stress in cells carrying temperature-sensitive alleles of RAT7/NUP159, RAT2/NUP120, and NUP145, indicating the export through nuclear pore complexes is required for the heat shock response. Surprisingly, however, we found that the selective cytoplasmic accumulation of SSA4 mRNA did not depend on functional RNA1, PRP20, or GSP1. Temperature-sensitive mutations of the RNA1 or PRP2O genes affect pleiotropically the metabolism of all major classes of RNA in cells shifted to nonpermissive temperatures. Mutations of RNA1, PRP20, and GSP1 also lead to a block in nucleocytoplasmic export of poly $\mid \mathrm{A})^{+}$RNA and its accumulation in nuclei /Shiokawa and Pogo 1974; Amberg et al. 1992, 1993; Forrester et al. 1992; Kadowaki et al. 1993; Schlenstedt et al. 1995).

One possibility is that the Gsplp system is the target used to block export of most mRNAs following heat shock. This could occur by either direct or indirect mechanisms. Although mechanistic details are emerging about the roles of $\mathrm{Ran} / \mathrm{Gsplp}$ in protein import (Melchior and Gerace 1995; Melchior et al. 1995; Sazer 1996), the precise roles performed by Ran/Gsplp in the export of poly $(\mathrm{A})^{+}$RNA are not yet known. However, a direct role for Ran/Gsplp in RNA export is probable, and thus export of poly $(A)^{+}$RNA could be directly affected through modulation of the Ran/Gsplp system.

We think it unlikely that import of all nuclear proteins is blocked following heat shock, as proteins produced in response to stress are probably required in all cellular compartments. However, it is possible that cells contain more than one set of proteins that can play the role in nuclear protein import performed by the Ran/Gsplp system These other proteins could act to permit the continued nuclear import of a specific set of proteins and the continued nuclear export of SSA4 and other stress response mRNAs. Future studies will also focus on defining the gene products required for selective export of heat shock mRNAs and clucidating the mechanism by which export of most mRNAs is inhibited during the stress response.

\section{Materials and methods}

Strans and growth conditions

Yeast strains and plasmids are described in Tables 1 and 2, re spectively. Except where noted, cells were grown to early exponential phase at $23^{\circ} \mathrm{C}$ in YPD-rich medium or in synthetic com. plete medium lacking leucine (SC-Leu) liquid medium (Rose et al. 1989). For induction of the heat shock stress response, cells in the exponential phase of growth $15 \times 10^{6}$ to $2 \times 10^{7}$ cells $/$ $\mathrm{mll}$ were transferred to water baths at the appropriate temperature. The stress response was also induced by the addition of cthanol to $10 \%$ (vol/vol).

\section{DNA and RNA manipulations}

Yeast transformations were performed by electroporation using an electroporator (Bio-Rad Laboratories, Melville, NY); cclls were allowed to recover in rich medium containing $1 \mathrm{M}$ sorbitol at $23^{\circ} \mathrm{C}$ for at least $1 \mathrm{hr}$ before plating. Escherichia coli strain DH5a was used for most cloning procedures.

To obtain PCR probes for in situ hybridization and Northern blotting, primers were designed by using the Oligo 4.0 software program (National Biosciences, Plymouth, MN) and obtained from Macromolecular Resources (Colorado State University, Fort Collinsl, the Dartmouth College Macromolecular Facility, or the Pennsylvania State University College of Medicine Macromolecular Core Facility (Hershey). Except as noted, standard PCR techniques were followed as directed by the Perkin-Elmer 
Table 1. Yeast strains

\begin{tabular}{|c|c|c|}
\hline Strain & Genotype & Source \\
\hline$\overline{M 3161 \mathrm{~A}}$ & mata ura3.52 his $3 \Delta 200$ tyr1 ade $2-1$ prp20.7 & Amberg et al. |1993| \\
\hline FY86 & mata ura3-52 his $3 \pm 200$ leu2 21 & F. Winston (Harvard Medical School, Boston, MA) \\
\hline EElb-35 & mata ura3-52 ade2.1 tyr1 gal his. 3200 & Hopper et al. $|1990|$ \\
\hline EElb & mata ura $3-52$ ade2 -1 tyr 1 gal ${ }^{-}$his $3 د 200$ ma $1-1$ & Hopper et al. 119901 \\
\hline LGY101 & mata ura3-52 his $3 \Delta 200$ leu $2 \Delta 1$ rat 7.1 & Gorsch et al. 1995$\}$ \\
\hline CHY 104 & mata ura3-52 his $3 \Delta 200$ leu2دi RAT2::HIS 3 & Heath et al. 119951 \\
\hline TDY 109 & mato ura3-52 his 31200 leu2s1 ade2.1 trp 1.1 ade 3 nup 145.10 & T. Dockendorff (unpubl.) \\
\hline CSY 107 & mato ura3.52 his3 1200 leu2 21 pYCpGALGSP1 & this study \\
\hline CSY 108 & mata ura3.52 his $3 \$ 200$ leu $2 \$ 1$ pYCpGALgspIval21 & this study \\
\hline
\end{tabular}

Cetus GeneAmp PCR Core Reagents protocol. DigoxigenindUTP was incorporated directly into probes during the PCR reaction. The number of digoxigenins incorporated along the probe could be controlled by adjusting the ratio of digoxigenindUTP to dTTP in the PCR reaction buffer. Although an in. creased ratio of dUTP-digoxigenin to dTTP increased the amount of digoxigenin-dUTP incorporated into each molecule of probe, higher ratios of digoxigenin-dUTP/dTTP decreased the efficiency of the PCR reaction. Because an antibody molecule is much larger than a nucleotide pair, the maximum fluorescent signal possible will be achieved before all dTTPs have been replaced by digoxigenin-dUTP. A ratio of $1: 4$ /digoxigenin-dUTP/dTTP\} provided a suitable compromise between high probe yield and maximum probe sensitivity $140 \mu \mathrm{M}$ digox. igenın-dUTP; $160 \mu \mathrm{M}$ dTTP final concentration).

To synthesize the SSA4 probe, a 270-bp fragment was amplified using plasmid EC702 (a gift from E. Craig, University of Wisconsin, Madisonl as a template and primers $5^{\circ}$. CAAACCCCATTAT GAGTAAA and 5'-TGGCTTATGACGATGAGAA To synthesize GAL1 probes from template pBM47 (kindly provided by Dr. Mark Johnston, Washington University Medical Center, St. Louis, $\mathrm{MO}$ ), the following primers were included in a single PCR reaction: 5'-GAAAAGTGCCCGAGCATAA and 5'-ACCGAGAAGTCACAATAATCA; 5'-AAAAATCCATCCATTACCTTA and 5'-TCCGGTGCAAGTTTCTTTA; 5'-TTAGCTGTTGTTAAAGCGAATA and 5'-TGATCCATACCGCCATTGT; 5'-CGAACACCCTTGTTGTATCTA and $5^{\prime}$-GCT CGATCCTTCTTTTCC; 5'-TGGAACGGCGATATTGAA and $5^{\circ}$-TTAAGACTTGAAATCTCACTGGA. To subclone the GAL1 gene downstream of the SSA4 promoter, the GAL1 gene was
PCR-amplified from pBM47 using primers 5 -TTTCGGTT. TGTGTTACTTC and 5 -GTGTTACTACTCGTTATTATTGT in a reaction that included UITma DNA polymerase Kit (Perkin-Elmer, Branchburg, NJ). The 1.7-kb DNA fragment was ligated to the Stul-linearized EC702 using standard procedure [Sambrook et al. 1989).

\section{Northern blotting}

Most Northern blot analyses were performed by preparing total yeast RNA as described |Guthrie and Fink 19911, and RNA was detected by chemiluminescence using a Genius 7 Luminescent Detection Kit (Boehringer Mannheirn). For the Northern blot in Figure 7, total RNAs were isolated from yeast cells as described (Najarian et al. 1987) and $20 \mu \mathrm{g}$ of each sample was subject to clectrophoresis on $1 \%$ agarose gels containing formaldehyde |Sambrook et al. 1989|. The gels were blotted to MSI MAGNA nylon membrane by capillary action. The end-labeled oligonucleotide, 5'-GTTGTACCTAAATCAATACC-3', which is complementary to nucleotide positions 16-35 within the SSA4 open reading frame, was used to detect $S S A 4$ RNA. A 0.9-kb BamHI$X$ bal fragment of the RNA1 gene was used to detect RNA1 transcripts. It was purified from plasmid pRU35/Traglia et al. $1989 \mid$ and labeled using random primers and ${ }^{32}$ P-labeled deoxycytidıne-triphosphate.

\section{In situ poly $(A)^{-}$RNA localization assay}

Cells shifted to $42^{\circ} \mathrm{C}$ or $37^{\circ} \mathrm{C}$ for specified times were fixed by adding formaldehyde to $4 \%$ and incubated for $90 \mathrm{~min}$ on a ro-

Table 2. Plasmids

\begin{tabular}{|c|c|c|c|}
\hline Plasmid & Markers & Comments & Source \\
\hline $\mathrm{EC} 702$ & $2 \mu$ LEU2 Amp ${ }^{r}$ & SSA4 gene in YEp351 & E. Craig (University of Wisconsin, Madison) \\
\hline $\mathrm{EC} 703$ & $2 \mu L E U 2 \mathrm{Amp}^{\mathrm{r}}$ & SSA1 gene in YEp351 & E. Craig (University of Wisconsin, Madison) \\
\hline YCpGAL-GSP1 & CEN4 URA3 Amp ${ }^{\mathrm{r}}$ & GSP1 under GAL control in $\mathrm{YCp} 50$ & P. Silver (Harvard Medical School) \\
\hline YCpGAL-GSP1 $1^{\text {val21 }}$ & CEN4 URA3 Amp & GSP1 1ale? under GAL control in $\mathrm{YCp} 50$ & P. Silver (Harvard Medical School) \\
\hline CSY109 & $2 \mu L E U 2 \mathrm{Amp}^{\mathrm{r}}$ & SSA4 $3 د 240$ in YEp351 & this study \\
\hline CSY 110 & $2 \mu$ LEU 2 Amp $^{r}$ & SSA4 3'J685 in YEp3j̈ & this study \\
\hline CSYl11 & $2 \mu L E U 2 \mathrm{Amp}^{r}$ & GAL1-SSA4 hybrid in YEp351 & this study \\
\hline CSY 112 & $2 \mu L E U 2 \mathrm{Amp}^{\mathrm{r}}$ & GAL1-SSA4\$747-2300 & this study \\
\hline CSY 113 & $2 \mu L E U 2 \mathrm{Amp}^{\mathrm{r}}$ & GAL1-SSA4\$1600-2300 & this study \\
\hline CSY 114 & $2 \mu$ LEU $2 \mathrm{Amp}^{\mathrm{T}}$ & SSA4 1-1680-GALl 650-1753 & this study \\
\hline CSY115 & $2 \mu$ LEU2 Amp Am $^{2}$ & $S S A 4^{C A A L .2}$ in YEp351 & this study \\
\hline CSY 116 & $2 \mu$ LEU2 Amp ${ }^{r}$ & $S S A 4^{U R A 3}$ in YEp 351 & this study \\
\hline pGFP-NLS & $2 \mu U R A 3 \mathrm{Amp}^{\mathrm{r}}$ & $\mathrm{ADH}_{5}, \mathrm{Gal4} \mathrm{AD}, \mathrm{SV} 40$ NLS. GFP & D. Goldfarb (University of Rochester, NY) \\
\hline
\end{tabular}


tator at room temperature. All other procedures for in situ hybridization to detect poly $(A)^{+}$RNA were carried out as described previously (Amberg et al. 1992; Gorsch et al. 19951. For detection of individual species of mRNA, probes ISSA4 or GAL1) were denatured in boiling water for $10 \mathrm{~min}$, immediately placed on dry ice, and added to prebybridization solution to a final concentration of $20 \mathrm{ng} / \mathrm{ml}$. Cells were incubated for $18 \mathrm{hr}$ at $37^{\circ} \mathrm{C}$ in a humid chamber.

\section{In vivo protein labeling}

In vivo labcling of heat shock proteins was performed as described by Nicolet and Craig 119911. Cells grown in SC-Met medium were transferred trom $2.3^{\circ} \mathrm{C}$ to heat shock temperatures for indicated times, and then $1.5 \mathrm{ml}$ of the culture was incubated with $150 \mu \mathrm{Ci}$ of a mixture of $\left[{ }^{35} \mathrm{~S} \mid\right.$ methonine and $\left.\right|^{35} \mathrm{~S} \mid \mathrm{cys}$. teine (Translabel, ICN Biomedicals) at the same temperatures in a prewarmed microcentrifuge tube for $15 \mathrm{~mm}$. The pre-heat shock control cultures were grown and labeled for $15 \mathrm{~min}$ at $23^{\circ} \mathrm{C}$. Total ycast protein extracts were prepared as described previously |Schultz et al. 1987 ). The protein concentrations were determined by the method of Peterson (1977). Protein extracts were resolved on a $5 \%$ stacking $/ 8 \%$ separating SDS-poly. acrylamide gel and transferred to nitrocellulose by electroblot. ting.

\section{Protein import assay}

A high-copy $(2 \mu)$ plasmid, pGFP-URA, containing the in vivo fluorescent protein GFP gene engineered with an SV40 NLS (constructed by Paul Roberts and obtained from David Goldfarb, University of Rochester, Rochester, NY! was introduced into wild-type yeast strain FY86. The GFP in this plasmid also contains sequences from the GAL4 activation domain and has a molecular mass of $\sim 45 \mathrm{kD}$. For protein import assays, cells were incubated at $23^{\circ} \mathrm{C}$ and grown to early $\log$ phase $\left(0.1-0.2 \mathrm{OD}_{(0)}\right)$ in SC-Ura medium. Cells were collected by centritugation and resuspended in residual supernatant in a $1.5 \cdot \mathrm{ml}$ Eppendorf tube. At time $t=0 \mathrm{~min}$, the culture was shifted to $42^{\circ} \mathrm{C}$, or ethanol was added to a final concentration of $10 \%$. Thereafter, at 2 -min intervals, an aliquot $(1 \mu l)$ was removed from the culture and placed on a glass slide to be observed immediately by microscopy for the location of green fluorescence. To inhibit additional protein synthesis, cycloheximide was added at $t=0$ to a tinal concentration of $10 \mu \mathrm{g} / \mathrm{ml}$. A Zeiss Axiophot photomicroscope equipped with a $100 \times$ oil-immersion lens and filters for FITC fluorescence werc used. The percentage of cells showing a nuclear signal was recorded at each time and photographed

\section{Acknowledgments}

We thank John Lis, Susan Lindquist, David Goldfarb, Susanna Keller, Helen Traglia, David Stanford, Lynn Sheldon, Ed Berger, and Catherine Heath for helpful discussions and advice. We thank Ken Orndorff and Ann Lavanway for assistance with microscopy and Reed Detar for assistance with phorographic reproduction. We thank Mark Johnston, David Goldfarb, and Betty Craig for plasmids and Mike Snyder tor antibodies. We thank Pamela Silver for advice and comments on the manuscript. This work was supported by grants from the National Institutes of Health to C.N.C. (GM.33998) and to A.K.H. [GM27930) and a core grant to the Norris Cotton Cancer Center, Dartmouth Hitchcock Medical Center, from the National Cancer Institute (CA-16038).

The publication costs of this article were defrayed in part by payment of page charges. This article must therefore be hereby marked "advertisement" in accordance with 18 USC section $17.3+$ solely to indicate this fact.

\section{References}

Acbi, M., M.W. Clark, U. Vijayraghavan, and J. Abelson. 1990. A yeast mutant, PRP2O, altered in mRNA metabolism and maintenance of the nuclear structure, is defective in a gene homologous to the human gene $R C C 1$ which is involved in the control of chromosome condensation. Mol. \& Gen. Genet 224: 72-80.

Amberg, D.C. 1992. "Isolation and characterization of essential genes of Saccharomyces cerevisiae required for the efficient nucleocytoplasmic trafticking of mRNA." Ph.D. thesis. Dartmouth College, Hanover, $\mathrm{NH}$.

Amberg, D.C., A.L. Goldstein, and C.N. Cole. 1992. Isolation and characterization of RAT1, an essential gene of Saccha romyces cerevisiae required for the efficient nucleocytoplasmic trafficking of mRNA. Genes \& Dev 6: 1173-1189.

Amberg, D.C., M. Fleischmann, l. Stagliar, C.N. Colc, and M. Achi. 199.3. Nuclear PRP20 protein is required for mRNA export. $E M B O$ /. 12: 23,3-241

Ashburner, M and I.J. Bonner. 1979. The induction of gene activity in Drosophila by heat shock. Cell 17: 241-254

Atkinson, N.S., R.W. Dunst, and A.K. Hopper. 1985. Characterization of an essential Saccharomyces cerevisiae gene related to RNA processing: Cloning of RNAl and generation of a new allele with a novel phenotype. Mol. Cell. Biol. 5: 907915.

Becker, I., F. Melchior, V. Gerke, F.R. Bischoff, H. Ponstingl, and A. Wittinghofer. 1995. RNA1 encodes a GTPase-activating protein specific for Gsplp, the Ran/TC4 homologue of Saccharomyces cerevisiae. 1. Biol. Chem. 270: 11860-11865.

Belhumeur, P., A. Lee, R. Tam, T. DiPaolo, N. Fortin, and M.W. Clark. 1993. GSP1 and GSP2, genetic suppressors of the prp2)-1 mutant in Saccharomyces cerevisiae: GTP-binding proteins involved in the maintenance of nuclear organization. Mol. Cell Biol 13: 2152-2161.

Bischotf, F.R., H. Krebber, T. Kempt, I. Hermes, and H. Ponstingl. 1995. Human RanGTPase-activating protein RanGAPl is a homologue of ycast Rnalp involved in mRNA processing and cransport. Proc. Natl. Acad. Sci. 92: 1749175.3.

Bond, U. 1988. Heat shock but not other stress inducers leads to disruption of a sub-set of snRNPs and inhibition of in vitro splicing in HeLa cells. EMBO 1. 7: 3509-3518.

Boorstein, W.R. and E.A. Craig. 1990. Structure and regulation of the SSA4 HSP70 gene of Saccharomyces cerevisiae. I. Biol. Chem. 265: 18912-18921.

Bossie, M., C. Lehoratius, G. Barcelo, and P. Silver. 1992. A mutant nuclear protein with similarity to RNA binding proteins interferes with nuclear protein import in yeast. Mol. Biol. Cell 3: 875-893.

Clark, K.L. and G.F. Sprague. 1989. Yeast pheromone response pathway: Characterization of a suppressor that restores mating to receptorless mutants. Mol. Cell. Biol. 9: 2682-2694.

Corbett, A.H., D.M. Koepp, G. Schlenstedt, M.S. Lee, A.K. Hop. per, and P.A. Silver. 1995. Rnalp, a Ran/TC4 GTPase activating protein, is required for nuclear import. /. Cell Biol. 130: $1017-1026$.

Craig, E.A. 1992. The heat shock response of Saccharomyces cerevisiae. In The molecular and cellular biology of the yeast Saccharomyces cerevisiae: Gene expression led. E.W. Iones, I.R. Pringle, and I.R. Broach', pp. 501-538. Cold Spring Harbor Laboratory Press, Cold Spring Harbor, NY. 
Dasso, M. 1993. RCCl and the cell cycle: The regulator of chromosome condensation takes on new roles. Trends Biochem. Sci. 18: 96-10].

Dreyfuss, G. 1986. Structure and function of nuclear and cytoplasmic ribonucleoprotein particles. Annu. Rev. Cell Biol. 2: $459-498$

Dreyfuss, G., J.J. Mantunis, S. Piñol-Roma, and C.G. Burd. 1993. HnRNP proteins and the biogenesis of mRNA. Annu. Rev. Biochem. 62: 289-321.

Fischer, U., J. Huber, W.C. Boelens, I.W. Mattai, and R. Lührmann. 1995. The HIV-1 Rev activation domain is a nuclear export signal that accesses an export pathway used by spe cific cellular mRNAs. Cell 82: 475-483.

Flach, J., J. Vogel, M. Bossic, A. Corbett, T. Jinks, D. Willins, and P.A. Silver. 1994. A yeast RNA binding protein shuttles between the nucleus and the cytoplasm. Mol. Cell. Biol. 12: 8399- 8407 .

Forrester, W., F. Stutz, M. Rosbash, and M. Wickens. 1992. De fects in mRNA $3^{\prime}$-end formation, transcription initiation, and mRNA transport associated with the yeast mutation prp20: Possible coupling of mRNA processing and chromatin structure. Cenes \& Dev. 6: 1914-1926.

Giardina, C. and J.T. Lis. 1995a. Dynamic protein-DNA architecture of a ycast heat shock promoter. Mol. Cell. Biol. 15: $2737-2744$

_- 1995b. Sodium salicylate and yeast heat shock gene transcription. 3. Biol. Chem. 270: 10269-10272.

Gorsch, L.C., T.C. Dockendorff, and C.N. Cole. 1995. A conditional allele of the novel repeat-containing yeast nucleoporin RAT7/NUI159 causes both rapid cessation of mRNA export and reversible clustering of nuclear pore complexes. 1 . Cell Biol. 129: 939-955.

Gross, D.S., K.E. English, K.W. Collins, and S. Lee. 1990. Genomic footprinting of the yeast HSP82 promoter reveals marked distortion of the DNA helix and constitutive occupancy of heat shock and TATA elements. I. Mol. Biol. 216: 611-631

Gross, D.S., C.C. Adams, S. Lee, and B. Stentz. 1993. A critical role for the heat shock transcription factor in establishing a nuclcosome-free region over the TATA-initiation site of the yeast HSP82 heat shock gene. EMBO 1. 12: 3931-3945.

Guthrie, C. and G.R. Fink. 1991. Guide to yeast genetics and molecular biology. Methods Enzymol. 194: 42.3-424.

Hamm, J. and I.W. Mattaj. 1990. Monomethylated cap structures facilitate RNA export from the nucleus. Cell 63: 109118.

Hartwell, L.H. 1967. Macromolecular synthesis in temperaturesensitive mutants in yeast. I. Bacternol. 93: 1662-1670.

Herruer, M.H., W.H. Mager, H.A. Raue, P. Vreken, E. Wilms, and R.J. Planta. 1988. Mild temperature shock affects transcription of yeast ribosomal protein genes as well as the stability of their mRNAs. Nucleic Acids Res. 16: 79177929.

Hopper, A.K., F. Banks, and V. Evangelidis. 1978. A yeast mutant which accumulates precursor tRNAs. Cell 14: 211-219.

Hopper, A.K., M.H. Traglia, and R.W. Dunst. 1990. The yeast RNA1 gene product necessary for RNA processing is located in the cytoplasm and apparently excluded from the nucleus. 1. Cell Biol. 111: 309-321.

Jarmolowski, A., W.C. Boelens, E. Izaurralde, and I.W. Mattaj. 1994. Nuclear export of different classes of RNA is mediated by specific factors. I. Cell Biol. 124: 627-6.35.

Kadowaki, T., Y. Zhao, and A.M. Tartakoff. 1992. A conditional yeast mutant deficient in mRNA transport from nucleus to cytoplasm. Proc. Nati. Acad. Sci. 89: 2312-2316.

Kadowaki, T., D. Goldfarb, L.M. Spitz, A.M. Tartakoff, and M.
Ohno. 199.3. Regulation of RNA processing and transport by a nuclear guanine nucleotide release protein and members of the Ras superfamily. EMBO /. 12: 2929-2937.

Lee, M.S., M. Henry, and P.A. Silver. 1996. A protein that shutthes between the nucleus and the cytoplasm is an important mediator of mRNA export. Genes \& Dev. 10: 1233-1246.

Lindquist, S. 1986. The heat shock response. Annu. Rev. Biochem. 55: 1151-1191.

Lindquist, S. and E.A. Craig. 1988. The heat shock proteins. Annu. Rev. Genet. 22: 631-677.

McAlister, L. and D.B. Finkelstein. 1980. Alteration in translatable ribonucleic acid after heat shock of Saccharomyces cerevisiae. 1. Bacteriol. 143: 603-612.

Melchior, F., and L. Gerace. 1995. Mechanisms of nuclear protein import. Curr. Opin. Cell Biol. 7:310-318.

Melchior, F., B. Paschal, J. Evans, and L. Gerace. 1993. Inhibition of nuclear protein import by nonhydrolyzable analogues of GTP and identification of the small GTPase Ran/TC4 as an essential transport factor. J. Cell Biol. 123: 1649-1659.

Melchior, F., T. Guan, N. Yokoyama, T. Nishimoto, and L. Gerace. 1995. GTP hydrolysis by Ran occurs at the nuclear pore complex in an early step of protein import. /. Cell Biol. 131: $571-581$.

Meyer, B.W. and M.H. Malim. 1994. The HIV-1 Rev trans-activator shuttles between the nucleus and cytoplasm. Genes $\&$ Dev. 8: 1538-1547.

Michael, W.M., M. Choi, and G. Dreyfuss. 1995. A nuclear export signal in hnRNP Al: A signal-mediated, temperaturedependent nuclear protein export pathway. Cell 83: 415422.

Miller, M.I., N.-H. Xuong, and E.P. Geiduschek. 1982. Quantitative analysis of the heat shock responses of Saccharomyces cerevisiae. I. Bacteriol. 151: 311-327.

Moore, M.S. and G. Blobel. 1993. The GTP-binding protein Ran/TC4 is required for protein import into the nucleus. Nature 365: 661-663.

Morimoto, R., A. Tissières, and C. Georgopoulos. 1994. The biology of heat shock proteins and molecular chaperones. Cold Spring Harbor Laboratory Press, Cold Spring Harbor, NY.

Najarian, D., M.E. Dihanich, N.C. Martin, and A.K. Hopper. 1987. DNA sequence and transcript mapping of MOD5: Features of the $5^{\prime}$ region which suggest two translational starts. Mol. Cell Biol. 7: 185-191.

Nicolet, C.N. and E.A. Craig. 1991. Inducing and assaying heatshock response in Saccharomyces cerevisiae. Methods Enzymol. 194: 710-717.

$\mathrm{O}^{\prime}$ Brien, T. and I.T. Lis. 1991. RNA polymerase II pauses at the $5^{\prime}$ end of the transcriptionally induced Drosophila hsp70 gene. Mol. Cell Biol. 11: 5285-5290.

-1993. Rapid changes in Drosophila transcription after an instantaneous heat shock. Mol. Cell. Biol. 13: 3456-3463.

Osteryoung, K.W., H. Sundberg, and E. Vierling. 1993. Poly|A| tail length of a heat shock protein RNA is increased by severe heat stress, but intron splicing is unaffected. Mol. \& Gen. Genet. 239: 323-333.

Peterson, G.L. 1977. A simplification of the protein assay method of Lowry et al. which is more generally applicable. Anal. Biochem. 83: 346-356.

Pinol-Roma, S. and G. Dreyfuss. 1992. Shuttling of pre-mRNA binding proteins between nucleus and cytoplasm. Nature 355: 730-732.

Rasmussen, E.B. and J.T. Lis. 1993. In vivo transcriptional pausing and cap formation on three Drosophila heat shock genes. Proc. Natl. Acad. Sci. 90: 7923-7927.

Rose, M.D., F. Winston, and P. Hieter. 1989. Methods in yeast 


\section{Saavedra et al.}

genetics. Cold Spring Harbor Laboratory Press, Cold Spring Harbor, NY.

Russell, I.D. and D. Tollervey. 1992. NOP3 is an essential yeast protein which is required for pre-rRNA processing. 1 . Cell Biol. 119: 737-747.

Sadis, S., E. Hickey, and L.A. Weber. 1988. Effect of heat shock on RNA metabolism in HeLa cells. I. Cell. Physiol. 135:377386.

Sambrook, J., E.F. Fritsch, and T. Maniatis. 1989. Molecular cloning: A laboratory monual. Cold Spring Harbor Laboratory Press, Cold Spring Harbor, NY.

Sazer, S. 1996. The search for the primary function of the Ran GTPase continues. Trends Cell Biol. 6: 81-85.

Schlenstedt, G., C. Saavedra, J.D.J. Loeb, C.N. Cole, and P.A. Silver. 1995. The GTP-bound form of the yeast Ran/TC4 homologue blocks nuclear protein import and appearance of poly $(\mathrm{A})+$ RNA in the cytoplasm. Proc. Natl. Acad. Sci. 92: 225-229.

Schultz, L.D., K.J. Hofmann, L.M. Mylin, D.L. Montgomery, R.W. Ellis, and J.E. Hopper. 1987. Regulated overproduction of the GAL4 gene product greatly increases expression from galactose-inducible promoters on multicopy expression vectors in yeast. Gene 61: 123-133.

Shiokawa, K. and K.O. Pogo. 1974. The role of cytoplasmic membranes in controlling the transport of nuclear messenger RNA and initiation of protein synthesis. Proc. Natl. Acad. Sci. 71: 2658-2662.

Shukla, R.R., Z. Dominiski, T. Zwierzynski, and R. Kole. 1990. Inactivation of splicing factors in HeLa cells subjected to heat shock. J. Biol. Chem. 265: 20377-20383.

Tani, T., R.I. Derby, Y. Hiraoka, and D.L. Spector. 1995. Nucleolar accumulation of poly $|A|+R N A$ in heat-shocked yeast cells: Implication of nucleolar involvement in mRNA transport. Mol. Biol. Cell 6: 1515-1534.

Traglia, H.M., N.S. Atkinson, and A.K. Hopper. 1989. Structural and functional analysis of Saccharomyces cerevisiae wildtype and mutant RNA1 genes. Mol. Cell. Biol. 9: 2989-2999.

Vijayraghavan, U., M. Company, and J. Abelson. 1989. Isolation and characterization of pre-mRNA splicing mutants of Saccharomyces cerevisiae. Genes \& Dev. 3: 1206-1216.

Wilson, S.M., K.V. Datar, M.R. Paddy, J.R. Swedlow, and M.S. Swanson. 1994. Characterization of nuclear polyadenylated RNA binding proteins in Saccharomyces cerevisiae. I. Cell Biol. 127: 1173-1184.

Wu, C. 1980. The $5^{\prime}$ ends of Drosophila heat shock genes in chromatin are hypersensitive to DNase I. Nature 286: 854 860.

Yost, H.J. and S. Lindquist. 1986. RNA splicing is interrupted by heat shock and is rescued by heat shock protein synthesis. Cell 45: 185-193.

1991. Heat shock proteins affect RNA processing during the heat shock response of Saccharomyces cerevisiae. Mol. Cell Biol. 11: 1062-1068.

Yost, H.J., R.B. Peterson, and S. Lindquist. 1990. RNA metabolism: strategies for regulation in heat shock response. Trends Genet. 6: 223-227.

Young, M.R. and E.A. Craig. 1993. Saccharomyces cerevisiae HSP7O heat shock elements are functionally distinct. Mol. Cell. Biol. 9: 5637-5646. 


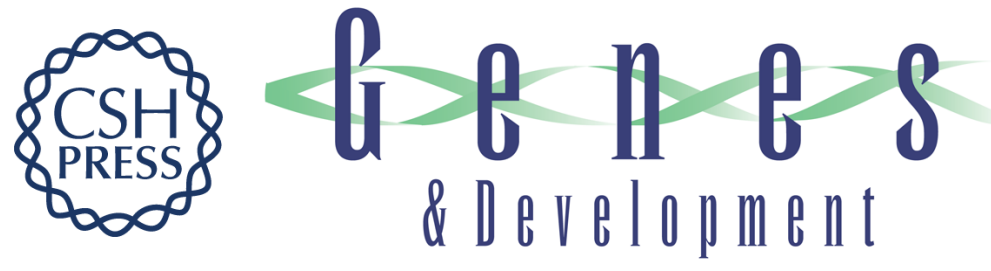

\section{Regulation of mRNA export in response to stress in Saccharomyces cerevisiae.}

C Saavedra, K S Tung, D C Amberg, et al.

Genes Dev. 1996, 10:

Access the most recent version at doi:10.1101/gad.10.13.1608

References This article cites 68 articles, 33 of which can be accessed free at:

http://genesdev.cshlp.org/content/10/13/1608.full.html\#ref-list-1

License

Email Alerting

Service

Receive free email alerts when new articles cite this article - sign up in the box at the top right corner of the article or click here.

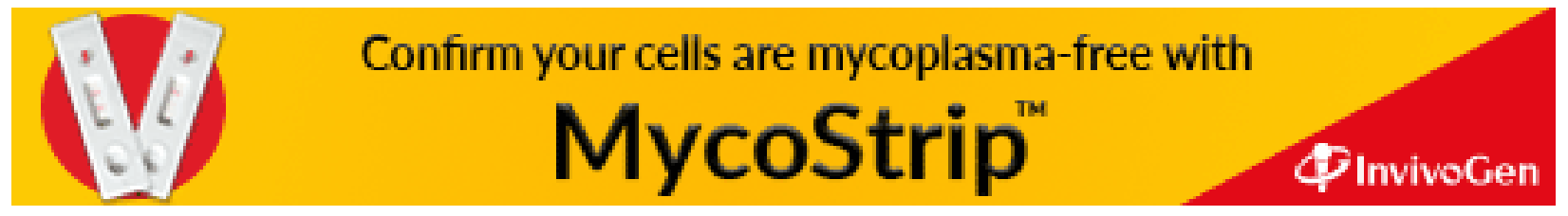

